\title{
Analisis Pengelolaan Barang Milik Daerah di Pemerintah Kota Kotamobagu
}

\author{
DEISSY MOKODOMPIT' ${ }^{1}$, JENNY MORASA ${ }^{2}$, JESSY WARONGAN ${ }^{3}$
}

\author{
1,2,3Program Magister Akuntansi, Fakultas Ekonomi dan Bisnis Universitas Sam Ratulangi \\ email : mokodompitessy@yahoo.co.id
}

\begin{abstract}
The management of the asset of a local government should be implemented properly so that it can give a description of the prosperity of the local government. The objective of this study is to analyse the management of the asset of the local government of Kotamobagu. The research method used for this study is a qualitative case study which focuses on the government of Kotamobagu city as its object of research. The data were collected in three ways, namely in-depth interviews, observation and study documentation. The key Informants for this study were determined by using purposive sampling to get the accurate and relevant information. The criteria for informant selection are that the informants should be the head and the asset manager of the regional work units (SKPD). The in-depth interviews used semi-structured questions and took about 45 to 60 minutes. The triangulation method was used in testing the validity or the credibility of the data and the sources. The data transcript of the interviews was analyzed by giving a theme/coding to the transcript and by making conceptualized and scientific statements. The results are summarized in narrative text interpretation. The results shows that some obstacles in the management of the asset of the regions in the Government of the Kotamobagu City. There are 4 inhibiting factors, namely: (1) securing and maintenance asset, (2) valuation asset, (3) elimination asset, (4) compliance.
\end{abstract}

Key Words: Local asset management, Regulation on local asset, Problem solving of local asset.

Abstrak. Pengelolaan barang milik daerah merupakan sesuatu yang harus dilaksanakan dengan baik agar dapat memberikan gambaran tentang kekayaan daerah, serta dapat digunakan untuk dasar penyusunan laporan keuangan, Penelitian ini bertujuan menganalisis Pengelolaan Barang Milik Daerah pada Pemerintah Kota Kotamobagu. Metode penelitian menggunakan kualitatif dengan studi kasus dan Pemerintah Kota Kotamobagu sebagai objek penelitian. Data diperoleh melalui teknik wawancara mendalam, pengamatan, dan studi dokumentasi. Informan kunci ditentukan secara purposive untuk mendapatkan hasil informasi yang tepat dan akurat. Kriteria informan adalah Kepala SKPD, Pengurus dan Penyimpan Barang. Wawancara menggunakan In-depth interview jenis semi terstruktur selama 45 hingga 60 menit. Metode triangulasi digunakan dalam pengujian validitas atau kredibilitas data dansumber. Data transkrip yang diuraikan dari hasil wawancara dianalisis dengan metode analisis kemudian diberi tema/coding dan dilakukan konseptualisasi pernyataan ilmiah. Hasil interpretasi disimpulkan dalam teks naratif. Hasil penelitian menunjukkan ada beberapa kendala dalam pengelolaan barang milik daerah di Pemerintah Kota Kotamobagu. Ada 4 faktor penghambat: (1) pengamanan dan pemeliharaan, (2) penilaian, (3) penghapusan, (4) kepatuhan.

Kata Kunci: Pengelolaan BMD, Regulasi BMD, Penyelesaian masalah BMD 


\section{Pendahuluan}

Siklus pengelolaan aset menjadi acuan bagi Pemerintah Daerah dalam mengelola kekayaan aset yang dimilikinya sehingga berimbas pada peningkatan manfaat dari kekayaan tersebut, baik dari segi jumlah maupun nilai kekayaan yang dimiliki. Sejak diterapkannya peraturan tentang pengelolaan barang milik daerah serta berbagai bentuk peraturan berlaku lainnya diharapkan mampu menjadi acuan dan kekuatan pemerintah dalam mengelola aset daerahnya.

Kenyataan dilapangan masih banyak laporan keuangan yang disusun tidak berkualitas hal ini dapat dibuktikan dengan pemberian opini dari Badan Pemeriksaan Keuangan (BPK). Berdasarkan hasil pemeriksaan BPK tahun 2015 dapat disimpulkan bahwa pengelolaan barang milik daerah di Pemerintah Kota Kotamobagu belum sepenuhnya memadai meskipun sudah mendapatkan opini WTP, namun selain dasar dari temuan BPK masih ada permasalahan lain terkait pengelolaan barang milik daerah yang hingga saat ini masih belum terselesaikan diantaranya mulai dari proses perencanaan yang belum berdasarkan standarisasi sarana dan prasarana kerja pemerintah daerah, penilaian barang milik daerah yang belum tuntas disebabkan barang yang diusulkan tidak keseluruhan dinilai, penghapusan yang masih menunggu regulasi, pengamanan barang milik daerah yang belum seluruhnya di dukung bukti kepemilikan serta masih lemahnya pengawasan karena masih banyaknya barang yang hilang. , meskipun demikian Pemerintah Kota Kotamobagu terus berupaya melakukan pembenahan dari segi pengelolaan barang milik daerah yang memadai.

Hasfi (2013) meneliti tentang pengelolaan barang milik daerah Pada Dinas Pendapatan, Pengelolaan Keuangan dan Aset Kabupaten Sintang dan hasilnya menunjukkan bahwa, pengelolaan barang milik daerah pada DPPKA Kabupaten Sintang belum sepenuhnya terlaksana dengan baik. Hal ini meliputi aspek perencanaan kebutuhan dan penganggaran, pengadaan, penerimaan dan penyaluran, penggunaan, penatausahaan, pengamanan dan pemeliharaan, pemanfaatan, penilaian, dan penghapusan barang milik daerah yang kurang sesuai dengan kebutuhan organisasi, sehingga menimbulkan inefisiensi dan kemubaziran. Pengelolaan barang milik daerah oleh DPPKA Kabupaten Sintang yang belum sepenuhnya terlaksana dengan baik dihadapkan beberapa kendala dibidang organisasi, sumber daya aparatur, aturan dan praktek manajemen pengelolaan barang yang belum sesuai dengan aturan yang ada.

Priyono (2013) yang meneliti keandalan informasi laporan keuangan daerah berbasis akrual (kajian pengelolaan aset tetap daerah kabupaten sampang) menunjukkan bahwa pengelolaan barang milik daerah Kabupaten Sampang belum dilaksanakan secara memadai menurut PP No. 6 Tahun 2006. Berdasarkan penerapan asas-asas pengelolaan barang milik daerah dan selanjutnya dikaitkan dengan karakteristik keandalan informasi, maka disimpulkan bahwa penyajian informasi aset tetap daerah pada Pemerintah Kabupaten Sampang belum andal. Dalam penelitian ini, pengelolaan aset difokuskan pada tahap perencanaan, pelaksanaan dan pelaporan dan kemudian diukur tingkat keandalan informasi aset.

Tujuan yang ingin dicapai dalam penelitian ini adalah untuk menganalisis kesesuaian pelaksanaan siklus/proses pengelolaan barang milik daerah dengan regulasi yang ditetapkan Pemerintah dan bagaimana upaya yang dilakukan Pemerintah Kota Kotamobagu guna memperbaiki pengelolaan barang milik daerah agar lebih baik.

\section{Model Analisis}

Model analisis pada penelitian ini dimulai dengan telaah paradigma melalui kajian isu-isu empirik tentang Pengelolaan Barang Milik Daerah, langkah berikut adalah fokus penelitian tentang Analisis Pengelolaan Barang Milik Daerah yang didukung dengan studi 
kepustakaan serta tahapan survey awal, selanjutnya adalah tahapan pengumpulan data, pengolahan data, periksa keabsahan data dan penyusunan laporan penelitian. Untuk lebih jelas model analisis penelitian ini dapat dilihat pada Gambar 3.1 berikut.

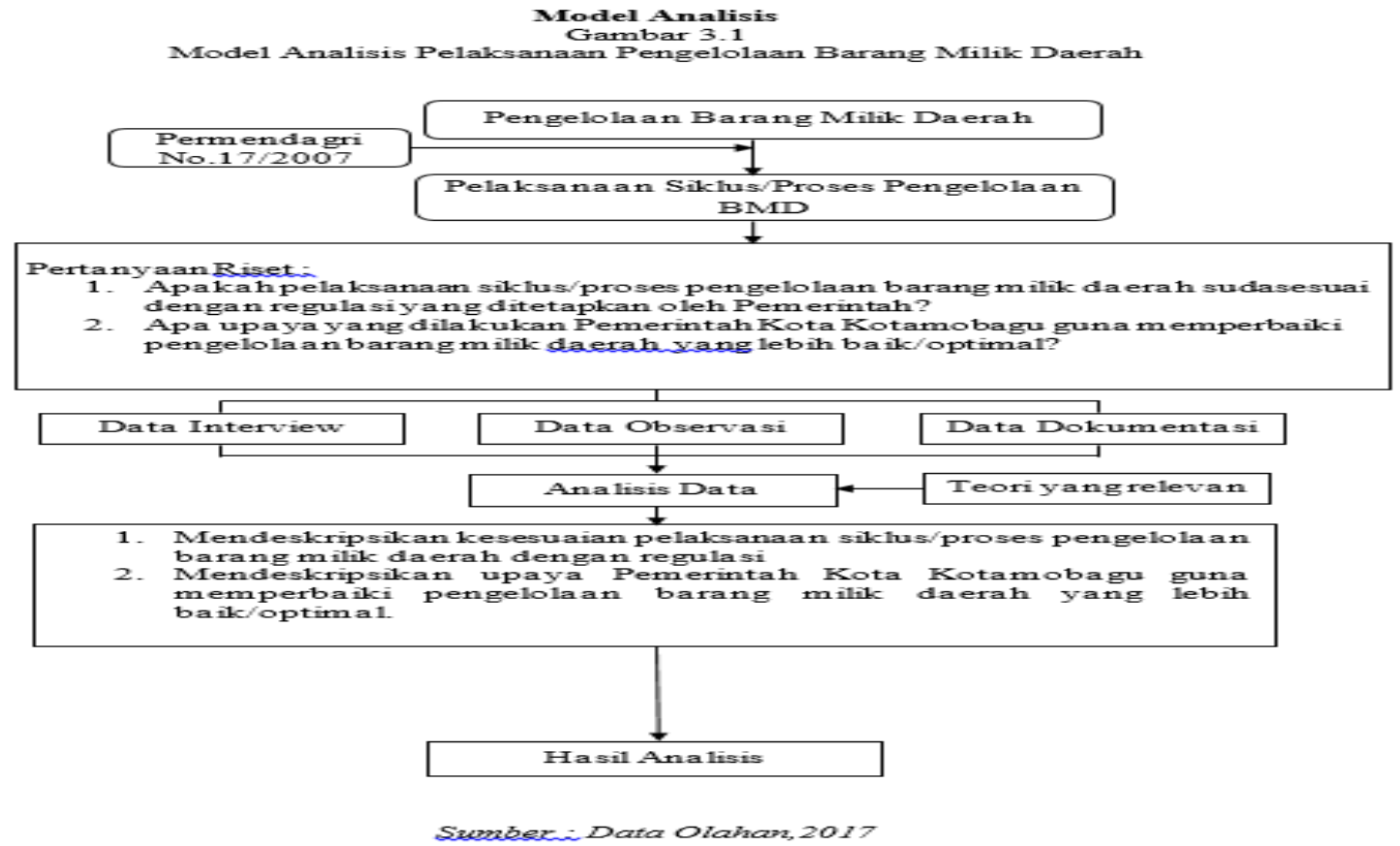

\section{Metode Penelitian}

Penelitian ini menggunakan metode kualitatif studi kasus (case study research). Menurut Yin (2014 : 1) penelitian studi kasus adalah sebuah metode penelitian yang secara khusus menyelidiki fenomena kontemporer yang terdapat dalam konteks kehidupan nyata, yang dilaksanakan ketika batasan - batasan antara fenomena dan konteksnya belum jelas dengan menggunakan berbagai sumber data. Adapun tujuan dari penelitian studi kasus yakni untuk menjawab pertanyaan " how atau why" terhadap sesuatu yang diteliti.

Teknik pengumpulan data yang ditempuh dalam penelitian ini adalah melalui pengamatan/observasi(observation), wawancara mendalam (indepth interview), dan dokumentasi (documentation).Selan-jutnya, uji keabsahan data dalam penelitian kualitatif meliputi uji credibility (validitas internal), transferability (validitas eksternal), dependability (reliabilitas) dan confirmability (objektivitas). Yin(2014)menyatakan bahwa ada enam sumber bukti yang dapat dijadikan fokus bagi pengumpulan data studi kasus dilakukan dengan studi dokumen, rekaman arsip, wawancara, observasi langsung, observasi pemeran serta dan perangkat fisik.

\section{Analisis dan Pembahasan}

Penelitian dilakukan selama \pm 3 (tiga) bulan sejak bulan November 2016 hingga bulan Januari 2017, wawancara dilakukan sesuai dengan pedoman wawancara kepada informan kunci yang sudah ditentukan menggunakan alat perekam untuk merekam seluruh isi wawancara, serta menggunakan instrumen pendukung antara lain buku catatan,alat perekam berupa audio/video, kamera untuk mendokumentasikan kegiatan dilapangan dan laptop untuk mengetik hasil penelitian dan rekaman sehingga berbentuk transkrip wawancara.

\section{Kesesuaian Pelaksanaan Siklus/Proses Pengelolaan Barang Milik Daerah Dengan Regulasi Yang Ditetapkan Pemerintah}

Pengelolaan barang milik daerah dilaksanakan berdasarkan asas fungsional, asas kepastian hukum, asas transparansi, asas efisensi, asas akuntabilitas dan asas kepastian 
nilai.Karena barang milik daerah merupakan salah satu unsur penting dalam rangka penyelenggaraan tugas pokok dan fungsi pemerintahan serta pelayanan kepada masyarakat.

Dalam pelaksanaan pengelolaan barang milik daerah pada Pemerintah Kota Kotamobagu secara umum telah sesuai dengan peraturan perundang-undangan terkait pengelolaan barang milik daerah yakni : Peraturan Pemerintah Nomor 27 tahun 2014 tentang pengelolaan barang milik Negara/Daerah, peraturan Menteri dalam negeri nomor 17 tahun 2007 tentang pedoman teknis pengelolaan barang milik daerah, dan peraturan daerah kota kotamobagu nomor 4 tahun 2014 tentang pengelolaan barang milik daerah. Namun ternyata pelaksanaan pengelolaan barang milik daerah pada Pemerintah Kota Kotamobagu masih terdapat ketidaksesuaian dengan regulasi antara lain dalam aspek perencanaan kebutuhan dan penganggaran, penilaian dan penghapusan barang milik daerah.

\section{Perencanaan Kebutuhan dan Penganggaran}

Perencanaan kebutuhan merupakan kegiatan untuk merumuskan rincian kebutuhan barang milik daerah dengan menghubungkan pengadaan barang yang telah lalu dengan keadaan sekarang sebagai dasar dalam melakukan tindakan yang akan datang. Berdasarkan hasil penelitian dapat disimpulkan bahwa proses kegiatan perencanaan kebutuhan dan penganggaran di Pemerintah Kota Kotamobagu walaupun sudah dilaksanakan sesuai regulasi yang ada, namun masih belum maksimal diakibatkan belum berpedoman pada standarisasi sarana dan prasarana kerja pemerintah daerah karena belum di dukung dengan ketersedian sarana dan prasarana yang memadai sesuai dengan standarisasi. Hal tersebut di sebabkan juga ketersediaan sarana dan prasarana kantor Pemerintah Kota Kotamobagu yang gedung/bangunan kantornya sudah lama, dan kalaupun dipaksakan penyusunan sesuai dengan standarisasi sarana dan prasarana masih terkendala dengan ada moratorium pembangunan gedung kantor oleh Pemerintah Pusat. Selanjutnya untuk penyusunan pembuatan gedung-gedung baru belum ada regulasi yang di tetapkan oleh Walikota serta harus melihat kesesuaian Anggaran Pendapatan dan Belanja Daerah juga.

Subagya (1995) menyatakan proses logistik terdiri dari fungsi perencanaan yang mencakup aktivitas dalam menetapkan sasaran - sasaran, pedoman, pengukuran penyelenggaraan bidang logistik. Sementara penentuan kebutuhan merupakan perincian dari fungsi perencanaan, bilamana perlu semua faktor yang mempengaruhi penentuan kebutuhan harus di perhitungkan.

\section{Pengadaan}

Proses pengadaan barang milik daerah di Pemerintah Kota Kotamobagu dilaksanakan oleh panitia pengadaan di tiap-tiap SKPD atau SKPD melalui ULP (Unit Layanan Pengadaan) dengan menggunakan LPSE (Layanan Pengadaan Barang Dan Jasa Secara Elektronik). Panitia pengadaan ditetapkan dengan Surat Keputusan Walikota dengan mengikuti mekanisme yang ditetapkan dalam aturan pengadaan.

Berdasarkan analisis hasil penelitian menunjukkan bahwa proses pengadaan di Pemerintah Kota Kotamobagu sudah dilaksanakan sesuai dengan aturan, karena sudah dilaksanakan oleh panitia pengadaan barang/jasa melalui ULP. Pemerintah Kotamobagu tahun 2015 mendapatkan penghargaan dari LKPP soal pengadaan akselerasi dari 500 kabupaten kota dan kementrian hanya 12 yang mendapat penghargaan dan salah satunya adalah kotamobagu makanya kotamobagu kalau dalam proses pengadaan tidak ada masalah lagi.

Subagya (1995) menyatakan, fungsi pengadaan merupakan usaha-usaha dan kegiatan - kegiatan untuk memenuhi kebutuhan operasional yang telah digariskan dalam fungsi perencanaan, penentuan kebutuhan dan penganggaran. Dimana pengadaan (procurement) 
mencakup cara pelaksanaanya, standar barang dan harga dan penyusunan spesifikasi barang.

\section{Penerimaan,Penyimpanan dan Penyaluran}

Proses penerimaan, penyimpanan dan penyaluran barang milik daerah di Pemerintah Kota Kotamobagu adalah tugas dari penyimpan barang, adapun prosesnya mulai dari merima barang hasil pengadaan yang telah di periksa oleh panitia pemeriksa barang dengan membuat Berita Acara Pemeriksaan,selanjutnya penyimpan barang mencatat tiap barang yang ada kemudian dibuatkan kartu barang untuk selanjutnya disalurkan berdasarkan petunjuk dari pimpinan.

Berdasarkan hasil wawancara dapat disimpulkan bahwa proses penerimaan, penyimpanan dan penyaluran barang milik daerah di Pemerintah Kota Kotamobagu sudah sesuai dengan regulasi yang mengatur tentang pengelolaan barang milik daerah, dalam hal penerimaan dan penyaluran tidak ada kendala yang masih ada kendala itu dari proses penyimpanan barang disebabkan tidak ada gudang penyimpanan atau gudang stokis di Pemerintah Kota Kotamobagu cuma tersedia satu gudang yaitu gudang untuk penyimpanan barang-barang rusak sementara untuk barang pakai habis tidak tersedia gudang itu disebabkan karena belum diterapkannya standarisasi sarana dan prasarana kerja pemerintah daerah. Hal ini terkait manajemen logistik yang merupakan proses mengenai fungsi penyimpanan dan penyaluran perlengkapan, yang telah diadakan melalui fungsi - fungsi terdahulu untuk kemudian disalurkan kepada instansi - instansi pelaksana. (Subagya,1995).

\section{Penggunaan}

Proses penggunaan barang milik daerah di Pemerintah Kota Kotamobagu yaitu SKPD membuat laporan barang milik daerah yang dimilikinya baik barang bergerak atau yang tidak bergerak disertai dengan usulan status penggunaan kepada Walikota melalui Sekertaris Daerah selaku pengelola BMD kemudian diteliti dan ditetapkan status penggunaannya oleh Walikota.Setelah di tetapkan status penggunaannya maka SKPD melakukan inventaris dan pencatatan terhadap BMD yang di pergunakannya.

Dapat disimpulkan bahwa proses penetapan status penggunaan barang milik daerah di Pemerintah Kota Kotamobagu sudah sesuai dengan tugas pokok dan fungsi SKPD yang bersangkutan dan regulasi yang mengatur tentang pengelolaan barang milik daerah.

\section{Penatausahaan}

Proses penatausahaan di Pemerintah Kota Kotamobagu meliputi 3 (tiga) tahapan kegiatan yakni pembukuan,inventarisasi dan pelaporan. Berdasarkan hasil wawancara dapat disimpulkan bahwa proses penatausahaan barang milik daerah di Pemerintah Kota Kotamobagu sudah sesuai regulasi yang mengatur tentang pengelolaan barang milik daerah.

\section{Pemanfaatan}

Pemanfaatan adalah pendayagunaan barang milik daerah yang tidak dipergunakan sesuai tugas pokok dan fungsi SKPD dalam bentuk pinjam pakai, sewa, kerjasama pemanfaatan, bangun guna serah, bangun serah guna, dengan tidak merubah status kepemilikan. Dalam hal pemanfaatan aset daerah pada Pemerintah Kota Kotamobagu baru sebagian bentuk pemanfaatan yang dilaksanakan yaitu sewa dan pinjam pakai.

Berdasarkan hasil wawancara dapat disimpulkan bahwa proses pemanfaatan barang milik daerah di Pemerintah Kota Kotamobagu ada dalam bentuk sewa seperti ada beberapa ATM yang di bangun di depan kantor Walikota atau di depan kantor Pemerintah itu di sewakan kepada pihak swasta, selanjutnya ada beberapa kendaraan dinas, bangunan gedung yang di pinjam pakaikan dan ada juga alat pertanian yang di pinjam pakaikan kepada masyarakat semua disertai dengan bukti berita acara pinjam pakai. Dapat di simpulkan 
bahwa proses pelaksanaan pemanfaatan sudah sesuai dengan regulasi yang mengatur tentang pengelolaan barang milik daerah.

\section{Pengamanan dan Pemeliharaan}

Pengamanan adalah kegiatan tindakan pengendalian dalam pengurusan barang milik daerah dalam bentuk pengamanan fisik, pengamanan administratif dan pengamanan secara hukum. Sedangkan pemeliharaan merupakan kegiatan atau tindakan agar semua barang selalu dalam keadaan baik dan siap untuk digunakan secara berdaya guna dan berhasil guna.

Dapat disimpulkan bahwa proses pengamanan dan pemeliharaan barang milik daerah di Pemerintah Kota Kotamobagu belum maksimal karena masih ada beberapa kendala diantara ada kendaraan dinas dan barang berupa laptop yang hilang itu terkait dengan pengaman fisik, serta masih ada beberapa bidang tanah yang belum memiliki bukti kepemilikan hal ini terkait dengan pengamanan secara hukum walaupun sudah ada bukti serah terima hibah sebagai bentuk penguasaan barang/aset namun berdasarkan standar akuntansi pemerintah (SAP) bahwa kepemilikan aset itu akan lebih handal jika disertai dengan bukti kepemilikan akan aset tersebut.

Hasil penelitian terdapat ketidaksesuaian antara regulasi dengan pelaksanaan yang ditemui di lapangan hal ini masih terkendala dengan pemeliharaan barang milik daerah yang diakibatkan kelalaian para pengurus dan penyimpan barang di SKPD yang tidak melakukan pencatatan barang yang di pelihara ke dalam kartu pemeliharaan barang. Hal ini menggambarkan ketidak patuhan para pejabat pengelola barang terutama pengurus dan penyimpan barang terhadap peraturan perundang-undangan sudah ada aturan yang mengatur tentang tugas pokok dan fungsi masing-masing pengurus dan penyimpan barang namun masih lalai dalam proses pelaksanaannya. Adapun laporan hasil pemeliharaan barang milik daerah nantinya akan dijadikan dasar dalam evaluasi proses pelaksanaan pengelolaan barang milik daerah.

Adapun fungsi pemeliharaan sendiri adalah usaha atau proses kegiatan untuk mempertahankan kondisi teknis, daya guna barang inventaris serta menjamin setiap logistik yang ada tetap berfungsi sebagaimana mestinya guna mendukung efisiensi organisasi. (Subagya,1995).

\section{Penilaian}

Penilaian barang milik daerah dilakukan dalam rangka pengamanan dan penyusunan necara daerah dan berpedoman pada Standar Akuntansi Pemerintah (SAP), proses penilaian yang dilakukan di Pemerintah Kota Kotamobagu adalah melalui usulan dari SKPD di sini SKPD membuat daftar usulan barang-barang yang akan di nilai kemudian memasukkan ke DPPKAD sebagai pembantu pengelola barang setelah itu DPPKAD membuat usulan permohonan penilaian kepada Walikota selanjutnya Walikota membuat SK Tim Penilai dari pihak KPKNL Manado,jadi dalam hal penilaian Pemerintah Kota Kotamobagu bekerja sama dengan KPKNL selaku pihak yang berkompeten dalam hal penilaian barang milik daerah.

Dapat disimpulkan bahwa proses penilaian di Pemerintah Kota Kotamobagu sudah sesuai aturan, namun masih terkendala dengan adanya aset yang berasal dari hibah kabupaten Bolaang Mongondow nilai perolehannya nol. Hal ini dapat mempengaruhi pengelolaan aset di Pemerintah Kota Kotamobagu karena penilaian tersebut termasuk aset yang berasal dari Kabupaten Bolaang Mongondow, dimana pengadaan barang tersebut tidak diketahui kapan diadakan sehingga akan sulit untuk mengetahui nilai perolehannya. Sebagaimana dijelaskan dalam Pernyataan Standar Akuntasi Pemerintahan Nomor 07 tentang Akuntasi Aset Tetap menyatakan dalam paragraf 24 " bila aset tetap diperoleh dengan tanpa nilai, biaya aset tersebut adalah sebesar nilai wajar pada saat aset tersebut diperoleh." 


\section{Penghapusan}

Penghapusan barang milik daerah merupakan tindakan penghapusan dari daftar barang pengguna/kuasa pengguna serta penghapusan dari daftar inventarisasi barang milik daerah. Adapun penghapusan barang tersebut dilakukan dengan menerbitkan SK Kepala Daerah tentang penghapusan barang milik daerah.

Berdasarkan analisis hasil wawancara dapat disimpulkan bahwa proses penghapusan di Pemerintah Kota Kotamobagu sudah sesuai aturan, namun belum optimal karena masih terkendala dengan adanya reklasifikasi dari aset tetap yang berasal dari reclas aset tetap karena barang hilang atau rusak belum dilakukan penghapusan. Hal ini akan mempengaruhi penyajian nilai aset di neraca karena masih ada barang yang dalam kondisi rusak dan hilang masih tercatat di neraca dan KIB , dikarenakan belum terlaksananya penghapusan atas asetaset yang dimaksud. Masalah lainnya proses penghapusan belum terlaksana karena masih menuggu SK Walikota untuk nantinya di jadikan dasar dalam penghapusan barang milik daerah.

\section{Pemindahtanganan}

Pemindahtanganan barang milik daerah merupakan pengalihan kepemilikan sebagai tindak lanjut dari proses penghapusan.Pemindahtanganan dilakukan melalui pelelangan umum/pelelangan terbatas dan disumbangkan atau dihibahkan kepada pihak lain, hasil penjualannya disetorkan di Kas Daerah.Akan tetapi bila barang milik daerah yang telah di hapus dari Daftar Inventaris Barang Milik Daerah masih memiliki nilai ekonomis maka dapat di pindahtangankan dengan cara di lelang atau di hibahkan.

Di Pemerintah Kota Kotamobagu sendiri belum melaksanakan pemindahtanganan karena sampai saat ini belum ada tanah dan bangunan yang Pemerintah Kotamobagu hibahkan ke pihak lain, karena terakhir sudah pernah mengajukan permohonan persetujuan untuk hibah gedung kantor imigrasi dan sudah di setujui oleh Walikota akan tetapi sampai saat ini masih terkendala dengan persetujuan dari DPRD belum ada persetujuan dari pihak DPRD sebagai lembaga pengawas pengelolaan barang milik daerah. Berdasarkan analisis hasil wawancara dapat disimpulkan bahwa proses pemindahtangan di Pemerintah Kota Kotamobagu belum pernah dilaksanakan proses pemindahtanganan itu, karena sudah pernah melakukan permohonan untuk hibah bangunan tapi ternyata tidak disetujui oleh DPRD.

\section{Pembinaan,Pengawasan dan Pengendalian}

Untuk menjamin kelancaran penyelenggaraan pengelolaan barang milik daerah maka fungsi pembinaan, pengawasan dan pengendalian sangat penting untuk menjamin tertib administrasi pengelolaan barang milik daerah. Bentuk pembinaan, pengawasan dan pengendalian di Pemerintah Kota Kotamobagu itu dilakukan oleh Walikota karena Walikota sebagai pemegang kekuasaaan pengelolaan barng milik daerah, karena Walikota berwenang dan bertanggung jawab atas pembinaan dan pelaksanaan pengelolaan barang milik daerah. Sedangkan pemantauan dan penertiban terhadap penggunaan, pemanfaatan, pemindahtanganan, dalam hal ini sudah dilakukan oleh Dinas Pengelolaan Keuangan dan Aset Daerah (DPPKAD) Kota Kotamobagu yang telah melakukan pemantauan terhadap barang milik daerah yang berada di lingkungan SKPD dan adanya pengawasan langsung yang dilakukan Inspektorat Daerah

Dapat disimpulkan bahwa proses pelaksanaan pembinaan, pengawasan dan pengendalian di Pemerintah Kota Kotamobagu sudah sesuai dengan peraturan, tapi masih ada temuan dari hasil pemeriksaan BPK yang menyatakan bahwa bidang aset DPPKAD masih lemah dalam pengawasan pemanfaatan pinjam pakai aset dan pengelolaan aset tetap yang sudah tidak memiliki masa manfaat baik itu rusak atau hilang. 
Mardiasmo (2004) menjelaskan bahwa pengawasan yang ketat perlu dilakukan sejak tahap perencanaan hingga penghapusan aset.dalam hal ini peran masyarakat dan DPRD serta auditor internal penting, pengawasan diperlukan untuk menghindari penyimpangan dalam perencanaan maupun pengelolaan aset yang dimiliki daerah.

Siregar (2004) mengatakan pengawasan dan pengendalian, dalam pemanfaatan dan pengalihan aset merupakan suatu permasalah yang sering terjadi pada pemerintah daerah saat ini. Dibutuhkan suatu saran yang efektif dalam neningkatkan kinerja aspek ini adalah melalui pengembangan SIMA (Sistem Informasi Manajemen Aset), melalui sistem ini maka transparansi kerja dalam pengelolaan aset sangat terjamin dan dapat diawasi dengan jelas karena keempat aspek di atas diakomodir dalam suatu system yang termonitor dengan jelas seperti system arus keuangan yang terjadi di perbankan sehingga penanganan dan pertanggung jawaban dari tingkat pelaksana hingga pimpinan mempunyai otoritas yang jelas.

\section{Pembiayaan}

Dalam rangka pelaksanaan tertib administrasi pengelolaan barang milik daerah di Pemerintah Kota Kotamobagu maka diberikan insentif bagi pejabat/pegawai yang melaksanakan pengelolaan barang milik daerah yang menghasilkan PAD, sedangkan bagi penyimpan barang dan pengurus barang dalam melaksanakan tugas diberikan tunjangan khusus yang besarannya disesuaikan dengan kemampuan keuangan daerah dan ditetapkan dengan keputusan Walikota. Adapun seluruh insentif maupun tunjangan khusus di bebankan pada APBD Kota Kotamobagu.

Berdasarkan analisis hasil wawancara dapat disimpulkan bahwa proses pembiayaan di Pemerintah Kota Kotamobagu sudah sesuai dengan peraturan, karena sudah tersedianya dana dalam APBD Kota Kotamobagu menyangkut pembiayaan untuk kegiatan pemeliharaan, tunjangan dan insentif para pejabat dan pengurus dan penyimpan barang dan pembiayaan lain sebagainya sesuai yang diatur dalam peraturan perundang-undangan.

\section{Tuntutan Ganti Rugi (TGR)}

Proses TGR dilaksanakan jika ada kerugian daerah akibat kelalaian dalam pelaksanaan pengelolaan barang milik daerah. Di Pemerintah Kota Kotamobagu sendiri sudah ada penyelesaian TGR yang dilakukan karena banyaknya barang yang hilang dan tidak tau lagi keberadaannya serta ada juga barang yang hilang karena dicuri pada saat pengguna barang bertugas tapi tetap dikenakan sanksi administrasi berupa TGR.

Berdasarkan analisis hasil wawancara dapat disimpulkan bahwa Pemerintah Kota Kotamobagu belum sepenuhnya patuh atas peraturan perundang - undangan, akibat penyalahgunaan /pelanggaran hukum atas pengelolaan barang milik daerah karena sudah menyebabkan kerugian Negara akibat banyaknya barang yang hilang. Serta adanya kelalaian pengurus dang penyimpan barang dalam mengelola administrasi pemeliharaan barang.

Mardiasmo (2009:22) menjelaskan bahwa akuntabilitas kejujuran dan akuntabilitas hukum (accountability for probability and legality), terkait dengan penghindaran penyalahgunaan jabatan (abuse of power) oleh pejabat dalam penggunaan dan pemanfaatan kekayaan daerah, sedangkan akuntabilitas hukum terkait dengan jaminan adanya kepatuhan terhadap hukum dan peraturan lain yang disyaratkan dalam penggunaan kekayaan publik.

Upaya - upaya perbaikan yang dilakukan oleh Pemerintah Kota Kotamobagu atas penyelesaian permasalahan pengelolaan barang milik daerah adalah sebagai berikut :

\section{1) Penilaian}

Terhadap penyelesaian masalah dalam pelaksanaan proses penilaian yaitu dengan melakukan penilaian atas barang -barang yang rusak dan yang sudah lewat masa manfaatnya berdasarkan usulan dari tiap SKPD untuk dinilai oleh pihak yang independen dalam hal ini dilaksanakan oleh Kantor Pelayanan Kekayaan Negara dan Lelang (KPKNL) 
Manado. Kemudian hasil penilaian yang sudah dilakukan oleh KPKNL nantinya akan ditindaklanjuti dengan proses pemindahtanganan (lelang) atas barang-barang yang telah dinilai, selanjutnya akan diterbitkan Surat Keputusan Walikota Kotamobagu tentang penghapusan barang milik daerah yang telah di lelang. Upaya lainnya yang dilakukan oleh Pemerintah Kota Kotamobagu adalah dengan mengadakan lelang pada hari Jumat tanggal 23 Desember tahun 2016 yang diadakan di aula kantor walikota sudah dilaksanakan lelang atas barang milik daerah bekerja sama dengan pihak KPKNL Manado.

\section{2) Pengamanan dan Pemeliharaan}

Terhadap penyelesaian adanya tanah dan bangunan yang merupakan aset hibah dari Pemerintah Bolaang Mongondow dipergunakan oleh pihak lain tanpa disertainya dokumen pinjam pakai akibat kelalaian dari pembantu pengelola barang maka Pemerintah Kota Kotamobagu akan mengirimkan surat kepada pihak-pihak yang menggunakan aset dimaksud untuk selanjutnya akan dilaksanakan penandatanganan perjanjian pinjam pakai tanah dan bangunan tersebut, dan sampai dengan tahun 2016 sudah ada beberapa pihak pengguna aset yang melakukan penandatangan surat perjanjiian.

\section{3) Penghapusan}

Selanjutnya upaya atas masalah aset lainnya (reclass) atas barang rusak dan hilang dan belum dilaksanakan penghapusan, sudah ada upaya yang dilakukan Pemerintah Kota Kotamobagu dengan melaksanakan penilaian pada tahun 2014 akan tetapi karena keterlambatan pelaksanaan pemindahtanganan (lelang) atas barang yang dimaksud sehingga telah melewati batas waktu masa berlaku hasil penilaian.

\section{4) Tuntutan Ganti Rugi (TGR)}

Terhadap penyelesaian TGR yang sudah diputuskan dalam sidang Mejelis Tuntutan Ganti Rugi dapat dilaksanakan sesuai ketentuan peraturan perundang - undangan yang berlaku.

\section{Penutup}

Kesimpulan penelitian berdasarkan hasil analisis terhadap kondisi yang dijumpai dalam penelitian dimana Pemerintah Kota Kotamobagu belum menerapkan standarisasi sarana dan prasarana kerja pemerintah daerah sehingga belum sesuai Peraturan Menteri Dalam Negeri Nomor 17 tahun 2007 tentang Pedoman Teknis Pengelolaan Barang Milik Daerah dan Peraturan Daerah Kota Kotamobagu Nomor 4 tahun 2004 tentang Pengelolaan Barang Milik Daerah. Pemeliharaan belum ada kesesuaian antara regulasi dengan pelaksanaan pemeliharaan barang milik daerah yang diakibatkan kelalaian para pengurus dan penyimpan barang di SKPD yang tidak melakukan pencatatan barang yang di pelihara ke dalam kartu pemeliharaan barang. Proses penilaian barang milik daerah di Pemerintah Kota Kotamobagu belum sepenuhnya dilaksanakan secara optimal, karena terkendala dengan ada SKPD yang tidak rutin menyampaikan aset yang rusak dan hilang jadi laporan keadaan aset tidak menggambarakan kondisi yang sebenarnya. Proses pengamanan dan pemeliharaan barang milik daerah di Pemerintah Kota Kotamobagu belum sepenuhnya dilaksanakan secara optimal, karena terkendala dengan belum adanya gudang yang memadai dalam penyimpanan barang. Proses penghapusan barang milik daerah di Pemerintah Kota Kotamobagu belum sepenuhnya dilaksanakan secara optimal, karena terkendala dengan regulasi masih rancu antara Permendagri 17 tahun 2007 dan Permendagri 19 tahun 2016 karena masih butuh penyesuaian. Pemerintah Kota Kotamobagu dalam hal pengelolaan barang milik daerah belum sepenuhnya patuh atas semua peraturan - peraturan yang telah di tetapkan oleh pemerintah, dibuktikan juga dengan adanya temuan BPK atas pelaksanaan proses pengelolaan barang milik daerah diantaranya proses Pemeliharaan dimana para pengurus dan penyimpan barang lalai dalam administrasi tidak membuat kartu pemeliharaan barang dan proses Tuntutan Ganti Rugi (TGR) banyak barang 
yang hilang seperti motor, laptop dan lain sebagainya yang sudah di proses TGR akibat kelalaian dari para pengguna barang.

Saran yang dapat diberikan dari penelitian ini : (1) Perlu adanya keterlibatan para pengurus dan penyimpan barang dalam hal perencanaan barang milik daerah untuk mengurangi kesalah dalam proses perencanaan sehingga pengelolaan barang milik daerah di Pemerintah Kota Kotamobagu akan lebih baik lagi, (2) Pemerintah Kota Kotamobagu harus membuat Standarisasi sarana dan prasara kerja pmerintah daerah karena selama ini Pemerintah Kota Kotamobagu belum mengacu pada standarisasi sarana dan prasarana kerja pemerintah daerah agar rencana kebutuhan barang milik daerah dapat disusun dengan memperhatikan tugas pokok danfungsi SKPD sehingga tugas pemerintahan daerah dan pelayanan publik dapat terlaksana dengan optimal, (3) perlu mengadakan sosialisasi, bimbingan dan pelatihan teknis bagi kepala SKPD, pengurus dan penyimpan barang milik daerah dan disusahakan mengundang juga para PPTK untuk meningkatkan komitmen, pemahaman dan kapasitas mereka dalam melakukan pengelolaan barang milik daerah, (4) perlu meningkatkan pengawasan dan pengendalian yang meliputi seluruh tahap dalam pengelolaan barang milik daerah supaya mengurangi TGR atas kehilangan barang milik daerah karena lemahnya pengawasan dan pengendalian yang dilakukan oleh para pengguna barang. Serta perlu membuat kartu kontrol yang akan digunakan dalam mencatat setiap barang yang telah dipelihara agar tidak ada lagi temuan yang berulang mengenai kelalalain mengelola administrasi pemeliharaan barang milik daerah, (5) Perlu melakukan penilaian atas barang -barang yang rusak dan yang sudah lewat masa manfaatnya berdasarkan usulan dari tiap SKPD untuk dinilai oleh pihak yang independen dalam hal ini dilaksanakan oleh Kantor Pelayanan Kekayaan Negara dan Lelang (KPKNL) Manado, (6) Mengupayakan akan terus melakukan proses penerbitan sertifikat untuk masalah aset tanah berupa hibah dari Pemerintah Bolaang Mongondow yang sampai dengan saat ini belum ada sertifikat.

\section{Daftar Pustaka}

Hasfi, Nyemas. 2013. Pengelolaan Barang Milik Daerah (Suatu Studi Pada Dinas Pendapatan, Pengelolaan Keuangan dan Aset Kabupaten Sintang). Magister IImu Sosial Fakultas IImu Sosial dan IImu Politik Universitas Tanjungpura Pontianak. Jurnal Tesis PMIS UNTAN PSIAN Vol.1, No 0001.

Mardiasmo. 2009. Akuntansi Sektor Publik. Yogyakarta : Andi

Priyono, K. (2013). Keandalan Informasi Laporan Keuangan Daerah Berbasis Akrual: Kajian Pengelolaan Aset Tetap Daerah Kabupaten Sampang. El Muhasaba: Jurnal Akuntansi, 4(1).

Republik Indonesia. 2010. Peraturan Pemerintah No. 71 Tahun 2010 tentang Standar Akuntansi Pemerintahan. Sekretariat Negara RI.

Republik Indonesia. 2007. Peraturan Menteri Dalam Negeri No. 17 Tahun 2007 tentang Pedoman Teknis Pengelolaan Barang Milik Daerah. Sekretariat Negara RI.

Subagya, M. S. (1995). Manajemen Logistik: Cetakan Keempat.

Siregar, Doli D. 2004. Manajemen Aset Strategi Penataan Konsep Pembangunan Berkelanjutan Secara Nasional Dalam Konteks Kepala Daerah Sebagai CEO's Pada Era Globalisasi dan Otonomi Daerah. Jakarta : PT. Gramedia Pustaka Utama.

Yin, Robert K. 2014. Studi Kasus: Desain \& Metode. 2014. Jakarta: PT. RajaGrafindo Persada. 